\title{
AUSTRALIAN EXPERIENCE WITH HIGH RATIO FABRIC FILTERS ON UTILITY BOILERS
}

\author{
C. Robertson and S. Strangert \\ Flakt Australia (Pty) Ltd
}

\section{INTRODUCTION}

The needs of the Electricity Commission of New South Wales (the Commission) in the application of fabric filter technology to utility boilers were born out of the particular characteristics of New South Wales coals, namely low sulphur content and high ash. These characteristics meant that the conventional electrostatic precipitator (cold side) technology which was generally acceptable in the United States and Europe in the 1960's and early 1970's, did not apply well to New South Wales power stations. Even with the relatively high allowable emissions at that time $\left(0.4 \mathrm{~g} / \mathrm{Nm}^{3}\right.$, equivalent to 0.32 $\mathrm{lb} / \mathrm{MBtu}$ for a typical New South Wales coal or 0.17 $\mathrm{gr} / \mathrm{scf}$ ), conventional gas cleaning technologies were unable to perform to expectations when new and their performance generally deteriorated with age. This was accelerated by the need for frequent water washing.

The extensive experience obtained by the Commission in electrostatic precipitator design and operation gained both through its pilot plant programmes and full size operating plant gave the organisation the confidence required to undertake an initial fabric filter pilot testing programme at Tallawarra Power Station in 1966. By 1972, the performance of the existing Centicell mechanical collectors at Tallawarra had deteriorated to such a degree that a full scale trial plant was installed on one half of a pulverised coal fired 30 MW boiler. The fabric filter was a mechanical shaker design using bags made of a woven synthetic fabric. Because of the low back end temperature a homopolymer acrylic (Dralon T manufactured by Bayer) became the standard after a short trial period.

With the success of the trials, a range of progressively larger boilers were subsequently retrofitted with both mechanical shaker cleaned (low ratio) plant as well as reverse pulse air (high ratio) plant. Installations were, where possible, carried out in the existing dust collection plant casings with the result that filtration velocity was often significantly higher than the perceived optimum. This was particularly significant until the development of bags of six metres or more in length allowed the effective reuse of even undersized precipitator casings.

Electrostatic precipitators were however still considered to have an economic advantage where new plant was being constructed. It was not until 1978 when the Commission made the commitment to construct a new 4 x $660 \mathrm{MW}$ power station at Eraring, with a requirement for clear chimney stacks, that a major base load station was planned to have fabric filtration from the outset. The four Eraring units, four more at Bayswater and two at Mt Piper (due to be commissioned in 1992/93) result in a total of 6,600 MW of new base load mechanical shaker cleaned units constructed since that time.

Pyrmont, of 3,432 bags of needle felted fibreglass. Fibreglass was required because of the high back end temperature at Pyrmont $\left(200^{\circ} \mathrm{C}\right)$ and in this case the bags were $3.76 \mathrm{~m}$ (12'4") long and $116 \mathrm{~mm}\left(4-1 / 2^{\prime \prime}\right)$ in diameter.

The larger precipitator casings meant that a much more conservative filtration velocity was possible $(0.02 \mathrm{~m} / \mathrm{s}$ or $4 \mathrm{ft} / \mathrm{min}$ ). The installation at White Bay was similar to that at Pyrmont except for the fractionally higher filtration velocity $(0.023 \mathrm{~m} / \mathrm{s}$ or $4.6 \mathrm{ft} / \mathrm{min})$, and the provision of new casings. The performance of units at both stations was excellent with clear stacks at all times and emissions of 0.004 to $0.02 \mathrm{~g} / \mathrm{m}^{3}(0.002$ to $0.01 \mathrm{gr} / \mathrm{scf})$ at full load. Unfortunately reliable bag life data was not able to be recorded as the units were decommissioned within a year of completing the installation. Pulsing frequency however, was increasing steadily at White Bay suggesting possible problems if operation had continued much longer.

\section{RETROFITS AT MUNMORAH}

As a result of high maintenance requirements and particularly poor performance from the $350 \mathrm{MW}$ Units 3 and 4 precipitators at Munmorah Power Station, a decision was made to replace the plant. These units were originally commissioned in 1969 and 1970. A review of the available options to provide satisfactory performance indicated that the most cost effective solution was to install fabric filters of the pulse jet cleaning style inside the existing precipitator casings (see Reference 4).

Due to the more intense cleaning system allowing the use of felted filter media and the ability to clean on line, pulse jet filters are able to operate at approximately double the filtering velocity of shaker or reverse flow filters. This coupled with the use of bags of six metres or more in length meant that a pulse jet filter could comfortably be installed in the casing of even these significantly undersized precipitators (SCA of $77 \mathrm{~m}^{2} / \mathrm{m}^{3} / \mathrm{sec}$ or 390 $\left.\mathrm{ft}^{2} / \mathrm{kcfm}\right)$.

A specification was issued for Munmorah in 1985 for fabric filters of the pulse jet type with a maximum filtration velocity of $0.02 \mathrm{~m} / \mathrm{s}(4 \mathrm{ft} / \mathrm{min})$ at the maximum expected boiler gas flow of $480 \mathrm{~m}^{3} / \mathrm{s}$ at $140^{\circ} \mathrm{C}$. New I.D. fans and fan inlet and outlet silencers were also included in the extent of supply.

Following an examination of the tenders and a review of the similar plants supplied around the world, it was 
decided to split the contract and purchase a Flakt plant for Unit 4 and a Howden plant for Unit 3.

The two plants very significantly in a number of key areas, with Flakt using "medium" pressure cleaning air at 280 $\mathrm{kPa}$, with round acrylic felt bags $7.2 \mathrm{~m}$ long and Howden using "low" pressure cleaning air at around $100 \mathrm{kPa}$, with oval acrylic felt bags $6 \mathrm{~m}$ long.

A full description of the installation and operation of the Flakt plant is being presented elsewhere but it is briefly described here for completeness.

\section{UNIT 4 - MUNMORAH - FLAKT}

Unit 4 was built by Flakt and commissioned in 1988, and to date has accrued some 8,500 operating hours, with very low emissions $\left(0.01 \mathrm{~g} / \mathrm{m}^{3}\right.$ or $\left.0.005 \mathrm{gr} / \mathrm{scf}\right)$, acceptable pressure drop and no bag failures.

Installation of the Unit 3 fabric filter is virtually complete with the Unit due to be returned to service in March, 1990.

\section{RETROFITS IN QUEENSLAND}

The Queensland Electricity Commission carried out similar retrofits to New South Wales to 24 small spreader stoker boilers in the Brisbane suburbs at Tennyson and Bulimba. Four pulverised coal fired $30 \mathrm{MW}$ boilers were also upgraded at Callide. High back end temperatures resulted in the use of Teflon filter bags which were $6 \mathrm{~m}$ long and $130 \mathrm{~mm}$ O.D. Filtration velocities were initially $0.022 \mathrm{~m} / \mathrm{s}(4.3 \mathrm{ft} / \mathrm{min})$ with all passes in service and 0.026 $\mathrm{m} / \mathrm{s}(5.1 \mathrm{ft} / \mathrm{min})$ with one gas pass isolated for maintenance. The design pressure drop was $1.37 \mathrm{kPa}\left(5.5^{\mathrm{N}} \mathrm{wg}\right)$ in order to utilise the existing ID fans with only the addition of new fan impellers. Excessive pressure drops occurred shortly after commissioning. The high pressure drop caused an extremely short cleaning cycle and thus led to excessive emissions.

The problems at Callide required additional bag area in the plant to reduce the filtration velocity to $0.017 \mathrm{~m} / \mathrm{s}$ $(3.35 \mathrm{ft} / \mathrm{min})$. The plant has performed satisfactorily since being extended.

\section{LIDDELL RETROFIT}

The Electricity Commission of New Wales 4 x 500 MW base to intermediate load power station at Liddell was commissioned between 1971 and 1974 and included large electrostatic precipitators from new. Historically, because of the higher than design inlet dust burdens (typically $30 \mathrm{~g} / \mathrm{Nm}^{3}$ or $15 \mathrm{gr} / \mathrm{scf}$ compared to the $18 \mathrm{~g} / \mathrm{Nm}^{3}$ maximum originally expected) and the high resistivity of the fly ash, the plant has always operated near the Clean Air Act emissions limit $\left(0.4 \mathrm{~g} / \mathrm{Nm}^{3}\right.$ or $\left.0.2 \mathrm{gr} / \mathrm{scf}\right)$. If an electrical problem occurred within any zone, emissions could only be controlled by reducing boiler load.

The very high sensitivity of fly ash resistivity to changes in gas temperature made special demands on the plant designers. Peak resistivity of the order of $10^{14} \mathrm{ohm}-\mathrm{cm}$ occurred at $135^{\circ} \mathrm{C}$ with rapid decreases occurring at both lower and higher temperatures. This temperature would have been the normal back end temperature at Liddell for a mixture of the discharged gas from the primary and secondary air heaters.

Gas flow emitting from both primary and secondary air heaters was therefore kept separate and fed through different primary, and secondary precipitator casings (SCA's. Primary $101 \mathrm{~m}^{2} / \mathrm{m}^{3} / \mathrm{sec}$ or $511 \mathrm{ft}^{2} / \mathrm{kcfm}$; Secondary $64 \mathrm{~m}^{2} / \mathrm{m}^{3} / \mathrm{sec}$ or $324 \mathrm{ft}^{2} / \mathrm{kcfm}$ ).

Several problems existed with the plant including:

a) Corrosion of secondary casings and collecting electrodes caused by low gas temperature $\left(107^{\circ} \mathrm{C}\right.$ or $225^{\circ} \mathrm{F}$ ) and regular water washing.

b) Poor rapping performance caused by sticky dust, function of (a) and also of the ammonia flue gas conditioning (which was added to improve performance). This performance improvement was realised but leads to very sticky deposits.

The worst maintenance situation for the plant is when one of the secondary casings is off line for maintenance at which time the filtration velocity will increase to $0.0253 \mathrm{~m} / \mathrm{sec}$ or $5.06 \mathrm{ft} / \mathrm{min}$. This is not seen as presenting any problem in the light of operating experience at Munmorah, and pilot plant tests at Liddell.

Because of the high inlet dust burden, the guaranteed bag life is less than Munmorah, at 17,520 hours whilst emission is guaranteed not to exceed $0.08 \mathrm{~g} / \mathrm{Nm}^{3}$ $(0.04 \mathrm{gr} / \mathrm{scf})$. This emission level was a requirement of the specification and represents the new licence level for the plant. Actual anticipated emissions are much less than this at $0.015 \mathrm{~g} / \mathrm{Nm}^{3} / 0.007 \mathrm{gr} / \mathrm{scf}$ ) and should ensure a completely clear stack.

\section{CONTINUING RESEARCH AND DEVELOPMENT}

The use of fabric filters on utility boilers is relatively new, with the first commercial unit going into service around the world in the early 1970's. At the time of commissioning in 1982-1984 the Eararing fabric filter installation was the largest in the world. The pulse jet fabric filters installed on Munmorah are also the largest of this type in the world, each being over double the size of the previous largest plant at Milner Power Station in Alberta, Canada. The installation at Liddell, being larger again than Munmorah, confirms the Commission's commitment to continue to develop this technology.

Because of the immaturity of these types of plants, the Commission has considered it appropriate to carry out extensive research and development work in this area. The Commission had been involved in development work with electrostatic precipitators and had been involved in pilot plant investigations with equipment suppliers prior to the installation of precipitators since the early sixties.

Pilot plant work by the Commission to date has led to major developments and improvements in the shaker fabric filter plants, in particular in the filter bag area. The eight compartment plant at Eraring is continuing in 
operation to screen potential replacement filter bags for Eraring, Bayswater and Mount Piper and at the same time provide an invaluable development tool for filter bag suppliers. The Commission has a policy of only purchasing replacement filter bags which have been both tested in this plant and also trialed in a single cell of the main plant.

In the area of the newer pulse jet fabric filters, it is probable that even more stands to be gained from research and development work. The Commission recently participated in a joint research project with the Electric Power Research Institute of the USA (EPRI) into the applicability of different pulse jet technologies to the utility industry. This project involved funding James Howden to operate two pulse jet pilot plants at Eraring. At the same time the Commission has participated in pilot plant trials with Flakt and Howden at Munmorah Power Station.

Three pilot plants were installed at Liddell by Ducon Micropul, Flakt and Howdens in order to gain the required site specific experience prior to submitting tenders for the Liddell fabric filter project. These pilot plants gained substantial experience for the companies, in the two years or so that they were installed prior to tenders being invited.

The operation of these plants has proven the viability of this technology to utility applications encompassing a broad range of boilers and burning a wide

It is expected that research and development work now underway will result in fabric filters using pulse jet technology continuing to become smaller and more economical in future years.

\section{ACKNOWLEDGEMENTS}

The assistance of the Electricity Commission of New South Wales Power Production and Power Plant Engineering Group Management and staff who are involved in the various projects and have contributed to the preparation of this paper is thankfully acknowledged.

\section{REFERENCES}

1. Messrs. G.J. Floyd and A.Th.M. Vandewalle "Australian Experience with Fabric Filters on Power Boilers", EPRI Conference on Fabric Filter Technology for Coal-Fired Power Plant, July, 1981. EPRI CS 2238 Published Proceedings.

2. Messrs. F.H. Walker and G.J. Floyed "Operating Experience in Australia with Fabric Filters on Power Boilers". EPRI Conference on Fabric Filter Technology for Coal-Fired Power Plants, November, 1983. EPRI CS 3257 Published Proceedings.

3. C. Robertson "Australian Experience with Fabric Filters on Power Boilers - An Update for 1985", Third EPRI Conference on Fabric Filter Technology for CoalFired Power Plants, November, 1985.

4. C. Robertson "Flue Gas Cleaning Using Fabric Filters in New South Wales - Current Experience and Recent Developments", 7th Conference on Electric Power Supply Industry, Brisbane, Australia, October, 1988. 